\title{
A Review of Ancient and Modern Concepts of Hyperlipidemia/Farț shahm fi al-dam
}

\author{
Roohi Bashir M.D.*, Yasmeen Shamsí M.D.** and Rais-ur-Rahman M.D.*** \\ Anant Naag, Jammu, Kashmir and New Delhi, India
}

\begin{abstract}
Ancient Yunani physicians were aware of dasam and shahm (fat) of the blood. They described the condition of fort shahm fir al-dom which is what we call now hyperlipidemia. They also described al-simna almufrita (excess of fat in the body) or what we call now obesity. They considered these two conditions a single disease. While we now know that they are different conditions, it is true that obese individuals frequently suffer from hyperlipidemia.
\end{abstract}

Key words: Hyperlipidemia, obesity, Yūnañ̄ medicine, al-simna al-mufrita, forț shahm fị al-dam

Introduction

Medical sclence is as old as mankind. Every civilization on the earth had its unique system of medicine. Classical medlcine included Bābh Ṭibb (Babylonlan medicine), Mișrn Țibb (Egyptian medicine), Hindi Tíbb (Ayurvedic medicine), șini Tibb (Chinese medicine) and Yūnañ̄ Ṭibb (Greek medicine). Yūnanī Țibb is a system of medicine that originated in Greece about 2,500 years ago and was adopted and developed by Muslims and others living in the areas of Syria, Iraq, Iran, Central Asia and India." The Yūnani (GrecoIslamic) system of medicine is a rich storehouse of remedies, principles and philosophies, which if practiced properly, can prove to be of immense value to science in general and medicine in particular, The theories, philosophies and therapies of this system are most appropriate to the human biologic system. Their remarkable results in day-to-day health problems as well as in complicated conditions have created implicit faith in the minds of people towards this system.

\footnotetext{
* Medical Officer, Jammu and Kashmir Health Services. Anant Naag, Jammu and Kashmir, India

-Lecturer, Faculty of Medicine, Jamia Hamdard, New Delhi, India

Associate Professor, Faculty of Ayurvedic and Yunani

Medicine, Delhi University, Delhi, India.

E-mail: yasmeenshamsi@yahoo.co.in
}

The concept of tabiyat and mizajj are unique. The term tabiyat is derived from the Arabic word tabii'a. It is also known as al-tabi' a al-mudabbira lil-badan. Tabiyat is a natural power, a prime mover, which, when it exists in a body, becomes the direct (proxjmate) cause for its active motion or rest. ${ }^{2}$ Mizajj (temperament) is the homeostasis in the internal environment of the body. It is specific for each individual, fluctuating between certain minimum and maxjmum limits.

In physlological conditions, țabiyat malntains homeostasis in the Internal environment of the body (mizaj). In case of disease or simply the body's fallure to reach its Ideal state, tabiyat acts to correct imbalances and non-ideal states. ${ }^{3}$

Man is subjected to various dangerous ailments in present time. Among these challenging diseases, fort shahm fi al-dam (literally "excessive fat in the blood") or hyperlipidemia is a major public health problem disproportionately affecting the affluent classes of society throughout the world. It accounts for millions of visits to doctors per year.

Hyperlipidemia is a pathological condition and the term is applied when the plasma cholesterol or triglyceride levels are increased above the normal levels. ${ }^{4-6}$ It is characterized by an excess of fatty sub- 
stances such as cholesterol, triglycerides and lipoproteins in the blood and is an important risk factor in the development of atherosclerosis. Lipoproteins include very low-density lipoproteins (VLDL), low-density lipoprotein (LDL), and intermediate-density lipoproteins (IDL). Chylomicrons are also considered as lipoproteins, and are composed of triglycerides, cholesterol and protein. High-density lipoprotein (HDL), or "good cholesterol", level is inversely related to the risk of coronary artery disease, as it is protective against the development of atherosclerosis. Hyperlipidemia is mainly of two types:

Primary: This may be caused by genetic factors and includes familial hypercholesterolemia, familial lipoprotein lipase deficiency, hepatic lipase deficiency and familial apoprotein C-II deficiency.

Secondary: This can be due to some other cause like diabetes mellitus, hypothyroidism, renal and liver diseases.

More than half of the coronary artery disease is attributed to the abnormities in the metabolism of plasma lipids and lipoproteins. Sedentary life style, high fat intake (greater that $40 \%$ of total calories, saturated fat intake greater than $10 \%$ of total calories, and/or cholesterol intake greater than $300 \mathrm{mil}-$ ligram per day), habitual excessive alcohol use and cigarette smoking are also associated with increased risk for atherosclerosis.

Defect in lipid metabolism causes hypercholesterolemia. LDL is the mediator of cholesterol and cholesterol esters uptake into many tissues. Free cholesterol is removed from tissue by HDL and transported to the liver for conversion into bile salts, Any disturbance can cause cardiac disease, peripheral vascular disease, and gall stones and other conditions. Elevated levels of fasting plasma total cholesterol in the presence of normal levels of triglycerides are almost always associated with increased concentration of plasma LDL cholesterol, since LDL caries 65-75\% of total plasma cholesterol. Rarely, patients with markedly elevated HDL can have increased plasma cholesterol levels. Elevations of LDL can result from a single gene defect, polygenic disorders or secondary effects of other disease states.
There is no direct reference to this disorder in the classical Yūnanī literature per se, but since hyperlipidemia is almost always assoclated with obesity, the term al-simna al-mufrita (obesity) can be said to encompass this disorder as used in these classical books, ${ }^{2,3,4}$ If we trace back the genesis of this problem, one will realize that the ancient Yünani scholars were well acquainted with the basic concept of this disorder. The ancient Yūnani physicians like Būqrāt (Hippocrates, 460-377 B.C) and Ibn Sina (980-1038 $C E)$ have described al-simna al-mufrita (obesity) in their magnum opuses. ${ }^{7-9}$ They mentioned dasam (fat) of blood in their books. According to Abū Sahal alMasihị, fat is 'udw mufrad (tissue) or 'udw-e-basitt (simple organ), and omentum or tharb, the fat that supports the outer surface of the intestine, is soft organ. He described fat's two types. One is soft (liquid) and has less propensity to solidity. For example, fat which is bound to muscles ('adalat) is called samn. The second type is solid or munjamid fat, which he called shahm, which adheres to the kidneys (adipose tissue). According to al-Masinī, fat (shahm and samn) are formed by the blood. The lubricant property of blood is due to the dasam. He also said that fat (shahm and samn) has less ghidhā'iyāt (nutrlents). Balgham (phlegm) and other fadulär (wastes) are formed by shahm and samn. ${ }^{10}$

According to Ibn Rushd, fat is a source of harärat (energy) in the body of human beings. He said fat (shah $\mathrm{m}$ ) is produced by blood and its average quantity in human being is a slgn of health and its decreased level indicates 'adam-e pukhtigi-e dam (undeveloped blood) and reduction of ghidha' (diet) for $a^{\prime}$ 'ia' (organs). He sald excess of fat is not good for health."1

Ibn STina also said, "Shahm and samn are formed by the ma' 'iyy att (water) and dasam (fat) of al-dam." According to Nafīs ibn Iwāz Kirmānī (d, 1448 CE), dasam-e latif of al-dam (good fat of blood) changes into ghidhà and maintains harärat al-țabī $a$ of lahm-e$a^{\prime}$ dē' (the natural heat of the muscular organs). On the other hand dasam fi al-dam (blood cholesterol), which comes with blood circulation to bārid a 'dà' or al-aghshiya (membranes), solidifies by the barüda (cold) and is known as shahm (fat). He also wrote that due to its lubricant property it makes these organs soft and mushy. ${ }^{12}$ From the above descrip- 
tion, it is clear that ancient Yūnañ̄ physicians were aware of dasam (shahm, fat) of blood. This dasam or shahm of blood has now been called lipids (cholesterol and triglycerides).

In the humoral theory, Būqrät has said that health is maintained by homeostasis of al-dam (blood), balgham (phlegm), safrä' (bile) and sawdā' (black bile). Imbalance of homeostasis leads to disease. Since dasam is present in blood in a certain proportion required for the maintenance of health, increased level of shahm and samn in the blood is su'-al-mizäj mâddi (abnormal temperament due to change in matter), which manifests itself with many symptoms. In the modern conception, this dasam is called liplds of plasma (cholesterol and triglycerides), the increased level of which leads to hyperlipidemia. So we can say that fart shahm fi al-dam is a marad khilți (humoral disease) and we are justified in calling this increase of dasam (cholesterol and triglycerides) in blood as fart shahm fi al-dam or hyperlipidemia.

In classical Yūnanī literature, a disease similar in varjous aspects such as etiology, clinical features and complications to fort shahm fi al-dam has been mentioned, namely al-simna al-mufrita (obesity). Despite the fact that hyperlipidemia and obesity are two different diseases, many times obese people do suffer from hyperlipidemia. The causes, signs, symptoms and complications of these two diseases are very similar. This might be the reason that our ancient Yūnani physicians considered these two conditions as a single disease. Also, at that time there was a lack of laboratory facilities and means of evaluation of lipids in blood, so our Yūnani physicians may have considered obesity and hyperlipidemia as one disease. Thus, they described al-simna al-mufrita as a whole (excess of fat in whole body) and could not specify the excess of fat in blood. Fart shahm fi al-dam is one of the complications of al-simna al-mufrita (obesity) and al-simna al-mufirta (obesity) can be sald to include this disorder as used in classical books.

\section{References}

1. Nigrmi H. Tarik-e-tibb. New Delhi, India: Taraqqi Urdu Bureau; 2000.

2. Ahmad I. Introduction to Al-Umoor-al-tabi'yah. Delhi, India: Saini Printers; 1980.

3. Bhika R, Haq H. Tibb-traditional roots of medicine in modern routes to health. South Africa: Mountain of Light; 2000.

4. William B. Text book of pathology. Eighth ed. Dadar Bombay, India: Wagus Publishing House; 1992. 5. Braunwald E, Anthony S, Fauci D et al. Harrison's principles of internal medicine. New York: McGraw Hill Company; 2001.

6. Weatherall DJ, Ledingham JGG and Warrell DA. Oxford textbook of medicine. Third ed. New York: Oxford University Press; 1996.

7. Būqurāt (460-377 BC). Malakiss-e-fasool-e-Būqurāți. Kantoori GH, translator (Urdu). Lucknow, India: Naval Kishore; 1903.

8. Ibn Sina (980-1038). Al-qanun. Lukhnow, India: Namipress; 1905

9. Ibn Sina (980-1038), Al-Qanun fi al-tibb, Kantoori $\mathrm{GH}$, translator (Urdu), Lahore, Pakistan: Naval Kishore (reprint by Sheikh Bashir and Sons); 1930. 10. Abū Sahal al-Masīhī (970-1010), Kitabul-mia-lìlMasīhī. Hyderabad, India: Nashrul Uloom Islamia; 1961.

11. Ibn Rushd (1126-1198). Kitabul kulliyat. Urdu translation. New Delhi, India: CCRUM; 1980.

12. Nafīs ibn Iwāz. Moalijat-e- Nafeesí. Lukhnow, India; Naval Kishore; 1906. 